\title{
Masculinization of Tragedy in Joseph Addison's Cato and George Lillo's The London Merchant
}

\section{Joseph Addison'un Cato ve George Lillo'nun Londralı Tüccar Eserlerinde Tragedyanın Maskülenleşmesi}

\author{
Sinan GÜL ${ }^{1 \oplus}$
}

IInstructor, TED University, Faculty of Arts and Sciences, Basic Sciences Unit, Ankara, Turkey

\section{Corresponding author:}

Sinan GÜL,

TED Üniversitesi, Fen-Edebiyat Fakültesi, Temel Bilimler Birimi, Ankara, Türkiye

E-mail: sinangul36@gmail.com

Date of receipt: 21.08 .2018

Date of acceptance: 25.10 .2018

Citation: Gül, S. (2018). Masculinization of tragedy in Joseph Addison's Cato and George Lillo's The London Merchant. Litera, 28(2), 233-252.

https://doi.org/10.26650/LITERA2018-0006
ABSTRACT

During the $18^{\text {th }}$ century, the development of gender and sexuality in the modern Western world was under tremendous impact of visual and literary culture. Considering this, by examining Addison's Cato. A Tragedy. By Mr. Addison. Without the Love Scenes (1764) (Latin version) and Lillo's The London Merchant (1731), this article analyzes the masculine features of the characters of $18^{\text {th }}$-century tragedies in England and investigates the reasons behind the dismissal and belittlement of love scenes and feminine qualities in those tragedies. In comedies, women and their qualities were openly ridiculed, while in tragedies, masculine values and patriarchal rules were overtly protected. Depicting societal norms and ideals, Cato and The London Merchant portray the evolving notions of masculinity.

Despite increasing female influence in political and social culture, love, often associated with feminine qualities, was belittled in domestic and public domains. In doing so, playwrights either entirely ignored the idea of using female characters in their plays, thus creating contextual errors of portraying husbands without wives or sons without mothers, or depicted women as the sources of passion that could potentially destroy society, men in particular. Therefore, the concept of love was neglected, undervalued, or dismissed, with playwrights rather offering patriotic or capitalist virtues to substitute the idea of love so that their plays would be deemed as appropriate for public appreciation. They also did not include any signs of sentiment, which was considered the reason behind a considerable decline in tragedies.

Keywords: Cato, The London Merchant, Eighteenth Century Tragedy, Joseph Addison, George Lillo

\section{Öz}

On sekizinci yüzyıl, modern Batı dünyasının toplumsal cinsiyet ve biyolojik cinsiyet kavramlarının gelişiminde fazlaca etkili oldu. Bu makale, Addison'un Cato adlı oyununun sonradan düzenlenmiş hali olan Cato. A Tragedy. By Mr. Addison. Without the Love (1764) ve Lillo'nun Londralı Tüccar (1731), adlı eserleri üzerinden, on sekizinci yüzyıl İngiliz tragedyasının maskülen karakterini analiz edip aynı zamanda aşk sahnelerine yönelik görmezden gelmenin ve hakir görmenin sebep ve sonuçlarını incelemektedir. Komedi kadınların ve onlara ait değerlerin açıcça hor görüldüğü bir tür olma özelliğini kazanmış iken tragedya ise erkeksi değerlerin ve patriarkal kuralların sıkı sıkıya kollandığı bir tür olmuştur. Toplumun hem normlarını hem de ideallerini gösteren Cato ve Lonralı Tüccar oyunları, maskülen değerlerin evrimine de tanıklık etmektedirler.

Kadınların politik ve sosyal kültürde etkilerinin artmasina rağmen, kamusal alanda, genellikle feminen özelliklerle bağdaştırılmış olan aşk hor görülmüştür. Bunu yaparken oyun yazarları, eşleri ortalıkta gözükmeyen kocalar ya da annesiz evlatlar yaratarak kadınların varlığını oyunlarında ya yok saymışlardır ya da kadınları bütün toplumun ama özellikle erkeklerin yıkımına neden olacak tutku kaynakları olarak lanse etmişlerdir. Bu yüzden oyun yazarları feminen kavramları oyunlarında ihmal etmiş, değersizleştirmiş veya tamamen görmezden gelmişlerdir ve bunun yerine vatan veya kapitalizm sevgisinin erdemlerini yerleştirerek, metinlerinin kitlesel beğeniye uygun olarak da onların gönlünü kazanmasını beklemişlerdir. Anahtar Kelimeler: Cato, Londralı Tüccar, On Sekizinci Yüzyıl Tragedyası, Joseph Addison, George Lillo 


\section{EXTENDED ABSTRACT}

For many scholars, the $18^{\text {th }}$ century is considered to belong to the genre of novel; but during those years, tragedies were also written with the intention to define the $18^{\text {th }}$-century English identity and qualities. Therefore, by examining Addison's Cato. $A$ Tragedy. By Mr. Addison. Without the Love Scenes (1764) (Latin version) and Lillo's The London Merchant (1731), this article analyzes the masculine characteristics of $18^{\text {th }}$ century tragedies as part of the English identity, while investigating the reasons why love scenes were attacked during this period.

There is an array of important themes in Cato that could be reinterpreted as a play; nonetheless, this article focuses on another version of Cato, which was published in 1764, in Latin, under the title Cato. A Tragedy. By Mr. Addison. Without The Love Scenes. One of the reasons behind editing Cato by eliminating love scenes stems from the assumption that society, at that time, undervalued love and dismissed any representation of it on stage. Harmonious with the Puritan code of ethics, cultural perceptions of the $18^{\text {th }}$ century render love and any type of passion provoked by it as being sinful. To purify a play from its "sinful" content and restore it to its mission of safeguarding morality and providing absolution, no trace of femininity was used. The London Merchant is taken from a ballad, which tells the unfortunate tale of an apprentice, George Barnwell, who is seduced by Millwood, and, as a result, steals money from his master and kills his uncle. Barnwell ending up at the gallows must have hit a particular nerve that drove Lillo to write a play on the subject. Lillo, however, wove the tragic events around the heralding news of the middle class. In his dedication, he submitted his sincerest respect to Sir John Eyles, who was a Member of Parliament and the sub-governor of the South Sea Company. Characteristically, the play transformed into a eulogy of the character Thorowgood, who was a renowned representative of the middle class and a virtuous portrait of a businessman. While delineating the plight of the apprentice, Lillo portrayed Millwood as an evil character whose femininity seemed to be the driving force for such hazardous business. Millwood was used as a scapegoat to criticize the passions of the time, consciously or unconsciously ostracizing negative feminine values. Lillo enriched the ballad's limited story by adding the obedient and virtuous Maria as Thorowgood's daughter, who presented the untainted woman desperately craved by masculine forces. By empowering men and subjugating women, plays were able to portray a masculine and strong Britain. The removal of women from tragedies is due to the fact 
that tragedies were somewhat out of favor during this era. Hence, excluding female characters can be seen as a playwright's way of saving the tragedy genre.

Although Cato and The London Merchant are completely different plays in terms of setting, period, and messages conveyed, the most remarkable similarity between the two of them is their influence and success in their respective eras. Many tragedies fell out of favor but these two plays became a hit, which was highly unexpected. The reason behind their triumph can be traced to their historical context; evidently, both the plays are pioneering as they contain noteworthy observations of the social, historical, and economic conditions of the $18^{\text {th }}$ century. Despite the textual perplexities, the audience welcomed these plays, primarily due to the ideas they conveyed.

In spite of increasing female influence in political and social culture, love, often associated with feminine qualities, was belittled in private domains. Therefore, the concept of love was neglected, undervalued, or dismissed, with playwrights rather offering patriotic or capitalist virtues as a substitute to the idea of love. With this, their plays would have no trace of sentiment, which was considered to be the reason behind the decline of tragedies, and will thus be appropriate for public appreciation. Sublimation of male protagonists as the sole source of virtue enabled playwrights to convey a moral message of caution against women. While reinforcing the idea with renderings from religious texts and constant biblical references, tragedies turned into a device of masculine empowerment to propagate phallocentric values. Perhaps intending to be show a different outcome, Addison and Lillo ultimately contributed to the creation of masculine characters in modern tragedies. 


\section{Introduction}

Tragedy has historically been ascribed with a dominant serious tone followed by an eventual destruction of its protagonist/s, whereas comedy is accredited with a cheerful tone and happy ending. It is often open to debate whether the former is superior to the latter, but a closer look at theater history might hint the glory of tragedy against comedy in terms of being restaged like Shakespeare's, Ibsen's or Miller's tragedies. Not only theater producers granted the prevalence of tragedy, but also Aristotle is the first of many eminent philosophers who rendered such a glorious position for tragedy (Halliwell, 1998, p. 34). His classic analysis of Greek dramatists such as Aeschylus, Sophocles and Euripides in Poetics defines tragedy as "the imitation of an action that is serious and also as having magnitude, complete in itself" (Halliwell, 1998, p. 22). He bestows it to purify the audience's senses through catharsis and create the feelings of pity and fear in order to accomplish its morally instructive mission (Abrams, 1999, p. 236).'

In addition to its purifying impact on audiences, tragedy has had social responsibilities such as primarily cleansing citizens' feelings and arousing fear and pity since the Ancient Greece. Since theater is broadly social in its goals, it concerns itself with certain topics in order to inform people and supply broad premises for a common understanding. For example, in the eighteenth century's cultural and social evolution of theater, tragedies served as an important contributor to the national identity and reflected specific economic and social concerns of the era. This essay purports to highlight specific features of tragedy within the eighteenth century and analyzes how feminine values were abjured from the content of tragedy in two identical plays of that period, Joseph Addison's Cato (1713) and George Lillo's The London Merchant or The Story of George Barnwell (1730-1731).

Although Cato and The London Merchant are completely different plays in terms of setting, time and messages, the most remarkable similarity between them is their influence and success in their era. Though many tragedies fell out of favor in one or two productions, these two became hit plays much unlike the expectations.

1 Around two thousand years later than Aristotle, English stage witnessed the evolution of tragedy which aimed more than to maintain the three unities (unity of time, place and plot) that have long been promoted. The issue of unities became a less, even non-existent, point on Restoration stage starting with Dryden's All for Love (1677): furthermore, Thomas Southerne's Oroonoko (1695) was an example that disregarded even the unity of a single plot. 
Numerous motives and reasons for their triumph can be traced in their historical context; particularly, both plays are pioneering in that they contain noteworthy observations of the social, historical and economic conditions of the eighteenth century. Despite the textual perplexities, audience welcomed these plays primarily due to the ideas they conveyed (Faller, 1998). ${ }^{2}$ The similarities between the plays might come from the tight network which influenced playhouses to choose similar patterns, plots and characters. Since there were two-three playhouses, there was a closed system which rarely permitted new experiments on the taste of the audience. Hence the playwrights imitated each other, plagiarized, modified and burlesqued each other's texts (Hume, 1980, p. 17).

The eighteenth century is considered to belong to the genre of novel by many scholars, but tragedy was also intended as a medium to define the English identity and qualities in the eighteenth century. Lisa Freeman argues that playwrights of the era deployed an "antitheatrical theatricalism" term to establish authority and legitimacy over audiences (Freeman, 1999, p. 472). Similarly, Kristina Straub thinks that theater played a major role at creating gender roles as spectator over the spectacle emerges in the eighteenth century (Straub, 1992, p. 17). By empowering men and subjugating women, drama portrayed a masculine and strong Britain. The attempt of removing women from the content of tragedy is the result of the fact that tragedy was comparatively out of favor on stage. This attempt could be interpreted as a way to save tragedy. Eugene Hnatko states that the popularity of novels and essays as literary forms and the rise of the middle classes as well as the decline of aristocracy, who has for centuries been considered to be the natural audience for tragedy, became prominent factors leading to the demise of true tragedy (Hnatko, 1971 , p. 461). In search of true tragedy, playwrights extolled pseudo-classical plays, and only a few among them, like Addison's Cato, was successful; almost all attempts of pseudo-classicism on stage were not deeply welcomed by the audience of the time. The performance statistics might shed light on the true situation. In 1700, after playing in Bath, the Drury Lane Company performed in 190 productions from October 6 to August 23, 1704. Only 65 of these performances were reserved for serious drama. Ten years later, tragedies took place on 72 nights out of 176, which might sign a change of taste among the audience. However, the majority of the

2 In his book The popularity of Addison's Cato and Lillo's The London Merchant, 1700-1776, Lincoln B. Faller takes these two tragedies as representatives of the century and his book investigates the reasons in detail why these two plays particularly received instant popularity by the audience. 
tragedies staged at that time were by William Shakespeare. New tragedies did not get a chance to be staged more than two or three times (Nicoll, 1995, pp. 55-59).

Augustan drama was often considered to be weak compared to the former periods by scholars and many efforts were made to be able to verify what it particularly lacked. The classical critics shared a belief that it was love that ruined the spirit of the tragedy. ${ }^{3}$ Pope, in the prologue to Cato, reminded the audience what the problem was: "Too long hath Love engross'd Britannia's Stage, / And sunk to Softness all our Tragic Rage" (4). In Mountfort's Zelmane (1704) the reason for the failure was also announced: "The Hero and the Lover long have been / The pleasing Bus'ness of the Tragick Scene" (Nicoll, 1995, p. 62).

\section{Cato and Cato without the Love Scenes}

In Cato's prologue, Alexander Pope, a close friend of Joseph Addison, points out that "Here tears shall flow from a more gen'rous cause" (v). This sentence, at the beginning, puts the stress on a different nature of tragedy as a whole. The emotions of the audience can also be aroused in comedies, but the notion of tragedy is unarguably more "gen'rous" and nobler. Pope reminds the readers that they will meet a hero, and what they are about to encounter is totally different from the 'unprivileged' comedies they are accustomed to watching. Here, one must stress that as an outstanding and prominent writer, Pope had a natural influence on the readers and audiences of his time as his writings and criticism were published in newspapers. The fact that such a close attention is being directed to the play prepares the audience for something spectacular. In that sense, the plot and characters of tragedies on stage require to be carefully chosen and designed. ${ }^{4}$

3 Dryden believed the lack of nature caused eighteenth century tragedy to fail. He pointed out: "A serious Play ... is indeed the representation of Nature, but 'tis Nature wrought up to an higher pitch. The Plot, the Characters, the Wit, the Passions, the Descriptions, are all exalted above the level of common converse, as high as the imagination of the Poet can carry them, with proportion to verisimility. (Hume citing from of Dramatick Poesie, Works, XVII. 74) Such a definition of serious tragedy might give the result that women or love are accepted as unnatural. Love and women are accepted to be the deformations of la belle nature. Can this feature be a legacy of the Ancient Greek drama which did not allow women on stage? Perhaps, but love stories in Ancient Greek tragedies did not really need female characters to reflect their sublimity. On the contrary, many classical tragedies from those times are still staged thanks to their portrayal of ideal love and sacrifice.

4 Addison's treatment of gender, conversely does not match what Pope scrutinizes in his prologue. Rather, he reflects an exemplar, ideal vision of femaleness in the play. (Schille, 2003, p. 32) 
Although Cato has a myriad of important themes to be reinterpreted as a play, I would like to focus my attention on another version of Cato published in 1764 under the title Cato. A Tragedy. By Mr. Addison. Without The Love Scenes. One of the reasons for editing the former play without the love scenes might stem from the assumption that society undervalues love and dismisses its forms on stage. Harmonious with the Puritan code of ethics, cultural perception of the eighteenth century renders love and any passion provoked by it as sin. To purify the play from its 'sinful' content and restore it on its mission of safeguarding morality and providing absolution, feminine touch was the primary element to be sacrificed. As Freeman puts it, "the resistance to the love scenes in Addison's tragedy was symptomatic of a broader politics of gender and genre that sought to position male characters as the exclusive and impregnable agents of tragedy and its ideological projects" (Freeman, 1999, p. 97). Thus, with virtually no textual editing, the main difference between the original and the latter version is the elimination of the female characters.

Cato without the Love Scenes does still have some love scenes despite its title's claim. Almost all language remains intact. However, the difference between the original and the revised version is in the treatment of female characters. Although their lines are completely preserved in the second revision, they are all attributed to the male characters. In order to save the facade of serious drama, the plausibility of the text is abandoned in most parts. For example, the substitution of Cato's son, Portius, instead of Marcia, causes textual gaps. Removing all of the love scenes induces the character of Cato to receive and absorb the whole emotional energy that was provided through the scenes between male and female characters. ${ }^{5} \mathrm{It}$ is clear that the new version of Cato has other concerns such as appealing to the colonist ideals of a supreme leader rather than a carefully-woven plot.

The reason that Cato had such a reputation in the post-Georgian England is hidden within its messages of liberty. Alexander Pope reports in a letter to John Caryll that "The numerous and violent claps of the Whig party on the one side of the theater, were echoed back by the Tories on the other" (Freeman quoting Pope, 1999, p. 97). It seems that political parties behaved bipartisan rather than claiming a patriotic virtue of liberty for their own benefit. If the situation in Rome was anything like that in

5 Freeman criticizes this concentration of all emotions on one character and points out that "The text has to work hard in the final act to iron out all the wrinkles it creates through the process of revision, and it does so by redirecting, and then subsuming, all emotional emerges under the figure of Cato." (109) 
England, then the audience sympathizing with Cato had to be against the tyranny of the monarchy, which definitely was not the case with the English audience. English audiences were well aware of the fact that it was a play meant to polish and recall the real virtues of English gentlemen. Since Cato and his family are historically strong supporters of Roman republicanism and traditions, his suicide rather than yield to the tyranny of Caesar epitomized Cato's commitment to liberty and the republic. It was not only the English who admired the unyielding character of Cato: The Americans who were tired of the English rule in their continent also loved Addison's historical character as he "offered a means for the Americans to explore ideas on how to retain their virtue when surrounded by the corruption and tyranny they found in the British Empire" (Harper, 2014, p. 57). Voltaire praises Addison and his play in his Letter on the English Nations: "The first English writer who composed a regular tragedy and infused a spirit of elegance through every part of it was the illustrious Mr. Addison." A lonely commander with "wisdom, bravery and admired by his surroundings" (Addison, 1993, p. 3) is the hero, and rest of the play serves as a background for him. All the characters exist to confirm his grandeur: even when they object to his orders, it is not because Cato is wrong, but simply because he favors not the mighty but righteous. It is the character of Cato and not the dramatic action that moves the play forward. Audience is expected to apprehend the English gentleman's spirit in Cato's character. In a way, no other character, particularly no women, are allowed to shatter this image. Thereby, a new version without love scenes, which basically drives women out of the stage, would reestablish missing pieces or complete unity without unnecessary parts of the play. ${ }^{6}$

Despite its success as a literary piece, Cato was criticized by eminent critics for not having all the necessary qualities of a proper tragedy. For example, an important critic of the eighteenth century, Dr. Wharton, comments on the defects of Cato in his review in The Literary Panorama. He states that "Cato is a fine dialogue on liberty, and the love of one' country; but considered as a dramatic performance, nay, as a model of a just tragedy, as some have affectedly represented it, it must be owned to want action and pathos: two hinges, I presume, on which just tragedy ought to necessarily to turn, and without which it cannot subsist." (Wharton, 1778, p.285) In addition to his criticism on characters and literary style, Wharton reveals the primary defect of Cato

6 In addition, Freeman includes foreign elements to the matter of "weakness" and analyzes that the critics' writings blame Italian, Spanish and French operas or comedies for implicating enflamed passions that distract from and threaten tragedy's designed purpose. 
when he points out that "The loves of Juba and Marcia, of Portius and Lucia, are vicious and insipid episodes, debase the dignity, and destroy the unity of fable." (Wharton, 1778, p. 285) Dr. Johnson, who emphasizes poetic superiority of the text rather than its dramatic capabilities, criticizes that there is "no magical power of raising phautastic terror or wild anxiety" (Johnson, 1778, p. 286). Thus, revised version attempts to vitalize tragic qualities by amplifying the figures of patriarch as a sign of power and authority.

The first scene opens with the dialogue of Cato's sons, Marcius and Portius, and introduces Cato and his conflict with Caesar. Brothers' recount of Cato's past virtues and deeds, as well as all events of his past life does not once even mention Cato's wife who is also their mother. Brothers remind each other of the advice their father used to give while they were growing up and once again, their mother seems to have made no contribution to their upbringing. Thus, questions on this dialogue start to arise: Why isn't Cato's wife ever mentioned either by her children or her husband? Is she a worthless and discreditable person? Are they ashamed of her? Can the mention of a female image perhaps as significant as Cato himself for having given birth to and raised Cato's heirs degrade his reputation? Rather, such isolation of Cato as a masculine character aims at creating a single focus on him, emphasizing his grandeur and semi-Godlike image. It is probable that Cato had a woman; perhaps more than one, unless, of course, his sexual inclination was different. However, the image of a female character responsible for upbringing Marcius and Portius other than Cato is never present in the play. Without the elimination of female characters, there is an inherent patricentric vein in Cato.

Similarly, love for another woman that turns Marcius and Portius into two rivals is dismissed and disallowed by their father as an eminent source of their weakness. It is rather surprising that none of drama or literature critics have so far investigated the existence of a mother in a family of four and attempted to unearth her hidden identity in this happy family portrait. Although Cato stands for the Stoic ideals of reason, unquestioning the absence of his relationships with the opposite sex makes his character only an orator of virtues. The celibate protagonist of this tragedy is consciously isolated and represented as a man without feelings, or, in other words, deprived of weakening sources caused by the presence of a feminine character. These sentences might clear the reason why love is not included in Cato's description of his own bravery: "... Marcius is not slow / To follow glory and confess his father. / 
Love is not to be reason'd down," (Addison, 2004, p. 13). Love cannot be controlled and in Cato it is apparently associated with anyone with feminine physical attributions. Hence, in Cato Without Love Scenes, the scenes between Lucia and Marcus or Portius are present; however, as a character Maria is expelled. Love, which cannot be reasoned, might drive these heroes to actions which they are not supposed to pursue. Therefore, the audience should be warned and cautioned against it. Such religious and moral codes embody a consistent contextual construction for most plays in the eighteenth century. The subversive impact of feelings for the opposite sex on most of the tragic figures is a reason why women, who are usually either mocked in comedies or ignored in tragedies in eighteenth century drama, are absent. As a reversal of Shakespearean Romeo and Juliet, Cato highlights a patriotic love's ascendancy over a romantic one.

Cato Without the Love Scenes was published in Latin fifty-one years after its premiere in 1713. The reason for this late publication might be another woman: Queen Anne whom can be credited with stopping or limiting Addison, or his publishers, to go any further in attributing negative connotations to all feminine values, which were so evident in the first publication. Schille, correspondingly, suggests that Cato was staged as a "manly" alternative to commonly popular "pathetic" tragedies of writers like Lee and Otway and she-tragedies of writers like Rowe and Banks (31). On the other side, Lisa Curtis-Wendlandt notes that Hamburg's prominent female intellectual Elise Reimarus' German translation and adaptation (ca. 1776) "engenders an alternative 'art of politics' —one that steers a consequentialist path toward the common good (Curtis-Wendlandt, 2013, p. 72).

Cato without the Love Scenes involves another kind of discrimination, differentiating it from other plays. The play was published with its Latin translation next to the English pages and, therefore, it was actually addressed for the well-educated parts of society. It is well known that in England women were not allowed to have university degrees until the beginning of the twentieth century, and for a woman and, of course, or a poor man to learn Latin was impossible unless they were wealthy or needed to be trained for aristocratic purposes. A Latin text might have been added to increase the volume of connection with Ancient texts or nostalgic heroism. Despite its philosophical excellence, Ancient Greece constituted a state where women and slaves had no rights at all. Keeping that fact in mind, publishing the English text together with the Latin translation might be efficient in order to understand the 
reckless and discriminatory principles of the publication. It is noteworthy that the addressee of the book was never meant to be a woman.?

In her book Character's Theater, Lisa Freeman argues that defenders of the English stage used tragedy as a standpoint in order to drive out all the irrational and feminine feelings, passions driven by foreign entertainments. In terms of the eighteenth century's social and economic dynamics, her thesis is profoundly reinserted, and I would like to expand her thesis by emphasizing the stoic bond between male characters.

Cato Without Love Scenese limits the subject of love. Instead of a romantic passion between a man and a woman, love for the wealth of the country, championing patriotic values and arousing patriotism are portrayed. Likewise, in the same century the Eastern literature turned the concept of mortal love into an eternal one. Most of the written products of the era were either hymns praising a certain person or starting with the eulogy for one, and generally constituted appraisals of Gods, prophets or emperors. The fear of a feminine touch or presence originating from the Holy books of Christianity and Islam thus obstructed or delayed the introduction of women into the social modern life. While love itself has always been blessed, women for a long time have been considered as the impure component of it, the whole subject being thus precluded. Such derogatory view of women being dominant in most parts of the world functioned discursively to strengthen the bond among men.

The existence of a brotherhood among men was not covert; women were also well aware of this 'secret' foundation, and unwittingly contributed to its dominance. In Cato, Lucia hints the strong ties between her rival lovers and emphasizes the precatory word told her passionately by Portius: "Portius himself oft falls in tears before me, / As if he mourn'd his rival's ill success" (Addison, 2004, p. 18). This invisible cement of patriarchal society is echoed in most social or cultural productions. At the end of the century, in her play The Belle's Stratagem, one of the female writers Hannah Cowley uses the concept of men's strong ties, which can be accounted for,

7 Another aspect of expelling women from the text is the commentary made by Voltaire in the introductory part of the book. Voltaire's words are given in French and translated into English on the opposite page. He criticizes the love scenes as the "insipid intrigue" that "murders the whole piece". Addison cannot save himself being harshly blamed for submit[ting] his austere genius to the manners of the age. (Freeman, 2013, p. 255) 
quite simply, by tradition, but it still proves how strong and concurrent this brotherhood was (Cowley, 2016). Doricourt points out, to prove his bond to his friend; "True, there I plead guilty, but I have never yet found any man whom I could cordially take to my heart and call friend who was not born beneath a British sky and whose heart and manners were not truly English" (Addison, 2010, I.iii., pp. 126-130). Analogous is the relationship between Portius and Marcius. Portius does not dare to declare his love for Lucia so that he would not hurt his brother's feelings once he realizes that Marcius is in love with her too. The bond between the two brothers is prior and superior to any other feeling or passion including love. Here again is a contradiction, for love between men is legitimate, and they never hesitate to demonstrate it, as opposed to love between a man and a woman. Thus, while the love for a woman bears a negative connotation in the play and is rendered as $\sin$, a man's display of affection (of course, stripped of homoerotic connotations) for another man is blessed and well-received.

Similarly, the love ascribed between Juba and Marcia is chaste in terms of masculine values. As a virtuous woman, Marcia is worthy to be loved since she is a reflection of her glorious father. The reason why Juba loves Marcia originates from her association with Cato; otherwise she is just like other women, as Juba points out, "The virtuous Marcia tow'rs above her sex/True, she is fair (oh, how divinely fair!)/ But still the lovely maid improves her charms/ With inward greatness, unaffected wisdom,/And sanctity of manners, Cato's soul/ Shines out in everything she acts or speaks ... Dwell in her looks, and with becoming grace/ Soften the rigour of her father's virtues" (Addison, 2004, p. 16). Even though feminine values are not directly mentioned or contorted in this quotation, the praise of a masculine character's reflection creates a binary opposition which promulgates the defeat of feminine characteristics. Marcia is worthy of praise because she is Cato's daughter.

The lines that derail Juba from the roads of honor are edited in the revision: "Juba will never at his fate repines / Let Ceasar have the world, if Marcia's mine" (Addison, 2004, IV. i. p. 45). In Cato without the Love Scenes the premise that brings Sempronius to his death is changed into a plot where Sempronius is caught while attempting to kidnap Cato and is slayed by Juba. A strong emphasis is put on Prince Juba in order to get him to his senses and reason. The part in the original where Marcia announces her affection for Juba in their verbal exchange is in the later edition insignificantly altered into a dialog between Juba and Porcius: 
PORCIUS: My joy! My best friend! All is bliss round me/

This, this is life, indeed! life worth preserving.

JUBA: How shall I speak the transport of my soul!

I'm lost in extacy! O my dear Porcius!

PORCIUS: Believe me, prince, before I thought thee dead,

I did not know myself, how much I lov'd thee.

JUBA: O fortunate mistake! O happy Juba!

Fortune thou now hast made me amends for all

Thy past unkindness: I absolve my stars. (Addison, 1995, III.ii. p. 32)

Such phrases announcing sympathy for another man should be rendered rather daring in the eighteenth century, but what enables this text to be published derives from the sense of brotherhood formed by a mixture of homoerotic feelings and patriarchal acceptance. For a male reader of the eighteenth century it would unravel a collaboration which functions like a password among male oriented markets.

In the second act, Cato finally appears and truthfully declares for whom this play was meant for from the beginning. Pope and Addison seem to make good use of straightforward addressees when they mean to preach the public. Pope addresses the Britons in the prologue to warn them against the dangerous effeminate effects of foreigners, and through Cato he calls fathers to hark what he is about to express much like Addison. His first word in the play is "Fathers" as if he excludes the whole opposite sex from the play or reminds the female audience / readers that noble tragedies are meant to show fathers' dignity. ${ }^{8}$

Cato's son Marcus is desperately in love with Lucia. Marcus's supposed intrepidity is lessened with his hopeless love and his passion. Lucia rejects him and his last words in the play are: "Oh, for some glorious cause to fall in battle! / Lucia, thou hast undone me: thy disdain / Has broke my heart;' 'tis death must give me ease' (Addison, 2004, III.

8 Conversely, Allordyce Nicoll reports that female audiences participated more in tragedies than in comedies due to the fact that in the latter feminine qualities and identities were harshly criticized and vulgarized. Women, assumingly, preferred to be non-existent or co-assistants to the plot instead of being mocked in respect of affinity to tragedies of the time. Swift summarized the shift in his Thoughts on Various Subjects: "it is observable that the ladies frequent tragedies more than comedy" (Nicoll citing Swift, 1995, p. 25). The reason he explains is the way tragedy handles the issue of women: "that in tragedy their sex is deified and adored, in comedy exposed and ridiculed". In a historicized context, Swift's remark on the issue of women in dramatic forms might prove true; on the other hand it might show how the situation of the women was already internalized to national identity. 
i. p. 33). This outburst is not for liberty or another virtue but for love. Cato without the Love Scenes rewrites this scene to cut Marcus's disclosure as his soliloquys are covered with heroism and courage instead of love. Although most of the lines remain the same, any reference about his love affair with Lucia is purged from the lines. Such a revision enables a discourse in which Marcus is celebrated for his triumph against vain passions. There is no stain or doubt left on his demise because he fights for his virtues not because he is hopeless about conquering Lucia's heart. Hence, Cato's speech after his son's death circulates an emotional ardor through male channels (Freeman, 1999, p. 105).

\section{"May she prove a warning to others"}

Cato and The London Merchant are two important plays of the eighteenth century and they both focus on the issues of real virtue through love and friendship. The plot of Lillo's play is taken from a ballad which tells the unfortunate tale of an apprentice, George Barnwell who is seduced by Millwood, and, as a result, steals money from his master and kills his uncle. Barnwell's end at the gallows must have hit a popular spot that drove Lillo to write a play on the subject. Lillo, however, wove the tragic events around the heralding news of the middling class. In his dedication, he submitted his sincere respect to Sir John Eyles, who was a Member of Parliament and the subgovernor of the South Sea Company. The play characteristically turned into a eulogy of the character Thorowgood, who was an eminent representative of the middleclass and the virtuous portrait of a businessman. While delineating the plight of the apprentice, Lillo portrayed Millwood as an evil character whose feminine sex seemed to be the driving motive for such hazardous business. He used Millwood as a scapegoat to criticize the passions of the time, consciously or unconsciously ostracizing the negative feminine values. On the other hand, Lillo enriched the ballad's limited story by adding obedient and virtuous Maria as Thorowgood's daughter, and thus presented the untainted woman of the society that the masculine forces desperately craved.

The portrayal of Millwood brings the resemblance of her deeds to Thorowgood's. They both have the desire to profit from the labors of others. She gets money from people through trickery, whereas Thorowgood uses all the beneficiary business tricks, such as slave trading, colonizing and usury. The despotic rules of business are as harsh for the non-benefiting party as the results of Millwood's trickery. Thorowgood, 
reluctantly consents that "truth is truth, though from an enemy spoke in malice" (Lillo, 1995, IV.ii. p. 327). In that way, Millwood's arguments exchanged with Thorowgood's where they both advocate the "Method" or the "Arts" of Merchandize (Morrissey, 1998, p. 32). Thorowgood is constantly described with positive qualities. On the contrary Milwood seems to have the lowest degree among mankind. Thus, the methods she employs and advocates in her business have negative outcomes whereas reason is on the side of Thorowgood's mercantilism. In a similar manner, in Cato Syphax, who is one of the villains that rebel against the orders of Cato, oppose colonialism as well:

SYPHAX: The boasted ancestors of these great men,

Whose virtues you admire, were all such ruffians.

This dread of nations, this almighty Rome,

That comprehends in her wide empire's bounds

All under heav'n, was founded on a rape.

Your Scipious, Caesars, Pompeys, and your Catos,

(These gods on earth) are all the spurious brood

Of violated maids, of ravish'd Sabines (Addison, 2004, Il.i .p. 28).

Conflicts in a play cause a clash and that is how a plot takes action. One of the weak points of Cato and The London Merchant is that people who are against the common beliefs are either traitors or fallen women. It is difficult to prove the accuracy of a cause without a strong opposition. Although dominant ideology of the times was supported well in both plays, the unfashionable and opposite values are voiced comparatively weaker characters. It is uncommon for any play to lay the whole blame on one character. This can be tied to melodramatic impact of eighteenth century drama. In The London Merchant, Barnwell, despite being the agent of all crimes, at the end is forgiven, and there is an emphasized possibility that his soul might be relieved off his sins. With the religious references scattered in the text, Millwood and Barnwell's story duplicates Adam and Eve's scriptural tale, where Eve was tempted by the devil in order to persuade Adam to eat the forbidden fruit of knowledge. Women have been accused to degrade mankind from heaven and castigated for the pains mankind has suffered. Similarly, Millwoodis depicted as the sole cause of Barnwell's fall. She reminds the audience the biblical similarity: "... and I was doomed, before the world began, to endless pains, and thou to joys eternal" (Lillo, 1995, V.ii. p. 339). Contrary to the characteristics of an accomplice, Barnwell responds with a prayer: "O gracious heaven! extend thy pity to her: let thy rich mercy flow in plenteous streams to chase 
her fears and heal her wounded soul" (Lillo, 1995, V.ii. p. 339). The dialogue here establishes the belief that women are doomed to a tenebrous fate unless they are emancipated by men. The reason for such an approach to the text derives from the need of a devil whereby the motives of Millwood could be reasoned. In Lillo's play, Millwood embodies both the devil and the victim. The passions of a female might turn her into a devil unless she defeats her rapacious desire, like Maria does.

A similar reference to the religious sources is Barnwell's treatment of himself as a traitor: "Sure, such was the condition of the grand apostate, when first he lost his purity: like me, disconsolate he wandered, and, while yet in heaven, bore all his future hell about him" (Lillo, 1995, II,i. p. 302). The scene where Barnwell kills his saint-like uncle denotes a great similarity to the scene between Judas and Christ. Barnwell, just like Judas, kisses his uncle whom he stabbed a few minutes before. I believe the density of religious references is an attempt to bless the text which is a manifestation of the middling classes. The way a new-born baby, Lillo, is blessed in a church consecrates the new-born bourgeoisie by associating his private tale to biblical references. Barnwell, moreover, tries to confess on his knees to Thorowgood as if he is in a church or in front of a priest. The symbolic transformation of Thorowgood from merchant to a member of clergy underlines the shift in power dynamics which assigns the new ecclesiastical class as the one to drive the capital. Thorowgood, in addition, was defined to be as merciful as an angel. Thus, the play between the lines represents a battle between reason and passion. Reason epitomizes positive values of the English society in the eighteenth century. In addition to conduct of business guided by reason, religious and colonial conducts are some of the positive elements that are highly respected in the merchant's character.

Cato and the London Merchant share an ambiguous theme that needs to be addressed. It remains a mystery whom Cato might have represented in the play, as still is unknown whose tragedy it was in Lillo's play: the merchant's, the apprentice's, the uncle's or Millward's. The absence of focus on a single character, however, strengthens both plays' content as, despite having theatrical flaws, both plays reflected a multi-voiced version of the era's values. It is notable, for instance, that both writers are keen supporters of colonial affairs. The Roman imperial project delineates, in general sense, the British mercantile and colonial project which Addison rejoices in the Spectator. Through the character of Thorowgood, Lillo integrates the faith: 
THOROWGOOD: The late found western world's rich earth glows with unnumbered veins of gold and silver ore. On every climate and on every country Heaven has bestowed some good peculiar to itself. It is the industrious merchant's business to collect the various blessings of each soil and climate and, with the product of the whole, to enrich his native country. (Lillo, 1995, IIl.i. p. 306)

This particular passage is sonorous with the idea that imperialistic desires are by nature phallocentric, resembling in the act the process of a man 'conquering' a woman. Britain's image as the colonizer thus had to be masculine, phallocentric, unfeminine, as was best portrayed in the famous painting The Discovery of America by Christopher Columbus (1959) by Salvador Dali.

The last scene of Lillo's play was added after the premiere. Although there seems to be no clear explanation for such an editing, it seems that Lillo did not want to end the play with chaste Maria's love declaration, which might have functioned against the virtuous situation that the play aims to promote. Instead, while justifying Maria's disclosure, Millwood was finger pointed: "May she prove a warning to others, a monument of mercy in herself!" (Lillo, 1995, V.iii. p. 341). Millwood is not only portrayed as a malicious tempting evil but also she is inscribed with values totally antagonistic to the benefits of the Empire. She is the evil version of Thorowgood whose aim is to improve his country and society, but she does not hesitate to reveal the disgust she feels for the hypocrisy Christianity and colonialism constructed. Her way of governance in the colonies embodies an antithesis to Thorowgood's attitude of benevolence towards the colonies. She is partially allied with the tactics of England's despised enemy, Catholic Spain. As is rendered characteristic for her sex, she refuses to acknowledge her crime or repent. Her sincerity which reveals hidden secrets placed in Thorowgood's account books prepares her destruction (Freeman, 1993, pp. 119-120). Millwood is a cunning woman who uses her energy for forgery and her investigative tone is not welcomed by the society. One of the points for which she is punished is the fact that she goes against the nature of a woman of quality. The way she mirrors a woman has no common points with Maria or the image of woman Lillo contemplates: "If to seem what one is not, in order to be better liked for what one really is; if to speak one thing, and mean the direct contrary, be art in a woman - I know nothing of nature" (Lillo, 1995, I.ii. p. 229). What she advocates constitutes the moral of tragedy which warns the society to avoid such characters. 
She is well aware of masculine values for using women for their own profit and she is brave enough to tell it: "We are no otherwise esteemed or regarded by them but as we contribute to their satisfaction" (Lillo, 1995, Il.i. p. 296) Another male character, Trueman, reveals the charge against her: "To call thee woman were to wrong the sex, thou devil!" (Lillo, 1995, IV.i.p.328) Maria, on the contrary, justifies innocent and obedient women:

MARIA: "How falsely do they judge who censure or applaud as we're afflicted or rewarded here! I know I am unhappy, yet cannot charge myself with any crime more than the common frailties of our kind, that should provoke just heaven to mark me out for sufferings so uncommon and severe. Falsely to accuse ourselves, heaven must abhor; then it is just and right that innocence should suffer, for heaven must be in all its ways. Perhaps by that we are kept from moral evils much worse than penal, or more improved in virtue: or may not the lesser ills that we sustain be made the means of greater good to others?" (Lillo, 1995, IV,i., p. 321)

Maria's defense through patriarchal and biblical references is not good enough to save her virtue, but it criticizes the double-standards of the society because the solidarity among men does not exist for women. The recurrent theme of fraternity, discussed above in Cato, is present in The London Merchant as well. As Marcius and Portius are the closest people to each other, Barnwell and Trueman appear to be the best of friends in London Merchant. The scene between Trueman and Barnwell in the last act displays a well-portrayed example of such an affinity. The fifth act of The London Merchant includes a scene of reconciliation between two male figures whose vehement demonstration of affection deserves particular attention. When Trueman visits Barnwell in the prison, Barnwell responds, in part, by "throwing himself on the ground" (Lillo, 1995, V.ii. p. 335). Realizing that Trueman has "propose[d] an Intercourse of Woe" (Lillo, 1995, V.ii. p. 336), Barnwell embraces Trueman and asks him to "take some of the joy that overflows my breast!" (Lillo, 1995, V.ii. p. 336) although it is possible to view this scene with homosexual connotations due to their "mutual groans" (V. ii.p.337), their "sighs" (V.ii.p.335) and their "mingling tears" (V.ii.p.338) (Morrissey, 1998, p. 25). At first glance, this scene functions as the reintegration of Barnwell into maleoriented business world that constantly promotes the union of men. This bond which is a natural enemy of outsiders excludes all races and other sex from its divine space. It treats the passion felt for a woman as the scapegoat responsible for a man's demise. It 
is true that Millwood tempted Barnwell by her "feminine" tricks to steal and kill, but as an individual Barnwell is justified at the end of the play, whereas Millwood goes to the gallows without any penitence. Barnwell is portrayed as the gullible innocent tricked by the wiles of the charming older woman. Lillo offers a warning against women like Millwood. Nussbaum explains how the idea of getting rid of strong women was prominent in the eighteenth century: "The satirist's end, then, is to release men from the power of women by attacking the entire sex. Men need to free themselves from the power of the sex [Nussbaum's emphasis]. Ideally men will learn to live without women, who only confuse them, prove them fools, and then destroy them" (Nussbaum, 1984 , p. 109). Lillo does not let his character suffer because of a cunning woman. Barnwell's situation is compared with the Biblical one where another female devastated the paradise: "Sure was the Condition of the grand Apostate, when first he lost his Purity; like me disconsolate he wander'd, and while yet in Heaven, bore all his future Hell about him." (Lillo, 1995, Il.i. pp. 9-11) Lillo presents Millwood's seductive evil for his audience to contemplate the atrocities that innocent apprentice suffered. Moreover, Lillo's characterizations are accordant with the tradition of the masculinized female usurper, as portrayed in both Greek and Roman tragedy.

\section{Conclusion}

In terms of gender studies, eighteenth century tragedy is a genre that consists of representations of threatening women despite the Enlightenment movement. Women become a target as Lillo points out in his play: "Woman, by whom you are, the source of joy, with cruel arts you labor to destroy; a thousand ways our ruin you pursue, yet blame in us those arts first taught by you" (Lillo, 1995, p. 329). In comedy, women and their qualities were openly ridiculed and tragedy protected masculine values and rules more overtly. In doing so, playwrights either ignored entirely the presence of women in their plays, creating thus contextual errors of leaving husbands without wives or sons without mothers, or depicted women as the sources of passion that could be potentially destructive for the whole society, men in particular. Such sublimation of male protagonists as the sole sources of virtue enabled to convey a moral message of caution against women. Supporting the idea with renderings from religious text and constant biblical references, tragedy turned into a device of masculine empowerment to propagate phallocentric values. Having perhaps intended a different outcome while writing their tragedies, Addison and Lillo inevitably contributed to the cause of creating a masculine character for modern 
tragedy as in both plays; female characters have marginal ideologies and their representations do not serve the imperial aspirations. Thus, they emboldened the tradition that determined the form and content of many plays in the history of drama up until the late twentieth century.

\section{References}

Abrams, M. H. (1999). A glossary of literary terms. Boston, MS: Heinle \& Heinle.

Addison, J. (2004) Cato: A tragedy and selected essays. Indianapolis,Indiana: Liberty Fund.

Addison, J. (2010). Cato: A tragedy. By Mr. Addison. Without the love scenes. New York, NY: Gale ECCO.

Cowley, H. (2016). The Belle's Strategem. London, UK: Wentworth Press.

Curtis-Wendlandt, L. (2013). Staging virtue: Women, death, and liberty in Elise Reimarus's Cato. Journal of the History of Ideas, 74(1), 69-92.

Faller, L. B. (1988). The popularity of Addison's Cato and Lillo's The London Merchant, 1700-1776. New York, NY: Garland Publishers.

Freeman, L. (2013). Character's theater: Genre and identity on the eighteenth century English stage. Philadelphia, PA: University of Pennsylvania Press.

Freeman, L. (1999). What's love got to do with Addison's Cato? Studies in English Literature, 39(3), 463-482.

Halliwell, S., \& Aristotle. (1998). Aristotle's Poetics. Chicago, IL: University of Chicago Press.

Harper, K. (2014). Cato, Roman stoicism, and the American revolution. (Doctoral Dissertation). Available from ProQuest Dissertations and Theses Database. (UMI No. 9743523)

Hnatko, E. (1971). The failure of eighteenth century tragedy. Studies in English Literature, 1500-1900, 11(3), 459-468. Hume, R. (1980). The London theater world, 1660-1800. Carbondale: Southern Illinois UP. Johnson, S. (1778) "Review" in the literary panaroma. C. Retrieved from www.babel.hathitrust.org Lillo, G. (1995). The London Merchant or the story of George Barnwell. Eighteenth-Century Plays. New York, NY: Oxford UP.

Morrissey, L. (1998). Sexuality and consumer culture in eighteenth century England: 'Mutual love from Pole to Pole' in The London Merchant. Restoration and $18^{\text {th }}$ Century Theater Research, 13(1), 47-64. Mountfort, W. (2018). Zelmane: Or, the Corinthian Queen. A tragedy. New York, NY: Gale Ecco. Nicoll, A. (1995). A History of restoration drama, 1660-1700. Cambridge, UK: Cambridge University Press. Nussbaum, F. A. (1984). The brink of all we hate: English satires on women 1660-1750. Lexington, KY: The University Press of Kentucky.

Schille, C. B. K. (2003). Now, Cato: Addison, gender, and cultural occasion. Restoration and $18^{\text {th }}$ Century Theater Research, 18(1), 31-48.

Straub, K. (1992). Sexual suspects: Eighteenth century players and sexual ideology. Princeton, NJ: Princeton University Press.

Wharton, J. (1778) "Review" in the literary panorama. Retrieved from www.babel.hathitrust.org 